\title{
The Use of Instructional Media in PAI (Islamic Religious) Lesson in Elementary School
}

\author{
Ahmad Munjin Nasih \\ Achmad Sultoni \\ Maisyaroh \\ Universitas Negeri Malang Jl. Semarang 5 Malang \\ munjin.nasih.fs@um.ac.id \\ Ah. Zakki Fuad \\ Universitas Islam Negeri Sunan Ampel Surabaya \\ Ali Rif'an \\ STAIMA Al Hikam Jl. Cengger Ayam 25 Malang
}

\begin{abstract}
The teaching of Islamic education in elementary school in Indonesia has not been widely explored by researchers, while this subject is particularly important in developing students' character. This study aimed to describe the teaching of Islamic Education in elementary school in Malang, particularly in terms of the use of instructional media. Qualitative method with case study observational design and multi-site research design was chosen to meet the aim, including the use of structured-interview and observation as means of data collection. By using qualitative data analysis, it was found that (1) there were diverse teaching methods used by teachers, (2) teachers used various instructional media, both conventional and modern, (3) the quantity and quality of supporting facilities of the PAI lesson were considered sufficient, and (4) there were some internal as well as external factors that either supported or hampered the teaching of Islamic Education in elementary school.
\end{abstract}

Keywords: elementary school, Islamic education, learning media

\begin{abstract}
Abstrak: Kajian mengenai pengajaran Pendidikan Agama Islam (PAI) di Sekolah Dasar selama ini relatif belum banyak dilakukan. Padahal sebagai mata pelajaran inti, PAI mempunyai peranan penting dalampembentukan karakter siswa. Penelitian inibertujuanmenggambarkan bagaimana pembelajaran PAI di Sekolah Dasar di Malang Raya berlangsung, khususnya bagaimana penggunaan multimedia dalam proses pembelajaran. Untuk mencapai tujuan tersebut digunakan pendekatan kualitatif dengan rancangan studi kasus observasional dan multisitus. Teknik pengumpulan data yang dipilih adalah wawancara terstruktur dan observasi. Analisis data dilakukan secara kualitatif. Temuan penelitian ini menunjukkan bahwa (1) metode pembelajaran yang digunakan guru dalam mengajarkan PAI cukup variatif, (2) terdapat beragam media yang digunakan guru dalam pembelajaran PAI. Selain media konvensional, sebagian guru menggunakan multimedia modern,(3) fasilitas pendukung pembelajaran PAI di SD dapat dikatakan cukup memadai, dan (4) faktor pendukung maupun penghambat penggunaan media dalam pembelajaran PAI di SD bersumber dari internal sekolah dan luar sekolah.
\end{abstract}

Kata kunci: media pembelajaran, pendidikan agama Islam (PAI), sekolah dasar

It has been generally known that the low quality of education becomes the serious problem for the nation. The quality of education determines the quality of the nation (Himam, 2016). The great nation has a sufficient education, while underdeveloped nations surely do not have a sufficient education. Therefore, an educational reform needs to be conducted to improve the quality of education and the human resources.
According to Nurhadi et.al (2004:1) one of the important aspect in reforming the education, beside the curriculum reform and learning quality, is the effective learning method. The effective learning method is used to empower the students' potency.

This day, the conventional method is still used in the learning process. The conventional method is a model which the teachers seen as an all-round party who transferred knowledge and doctrine the students. 
The students seen as an object of knowledge, the teachers have full right to teach and the students have to listen without giving permission to argue. While the teachers are teaching, the teachers are the center of learning and the students cannot develop their critical thinking. More ironically, the process of learning is seen as a tool to pursue the targeted curriculum, the students' understanding seems to be ignored by the teachers.

The learning process portrayed in above explanation makes the condition in class becomes passive and there is no dialogue between the students and the teachers that become a spirit of learning. It makes the class monotonous; the students will feel bored and uncomfortable to learn. If they want to learn, it is because they are under pressure.

This phenomenon happens in PAI lesson (Islamic religious lesson) in public school. Based on Depdiknas Curriculum Center (2004), the situation happens because of the weak human resources in developing the variety of approach and method. However, sometimes to cover up the weakness, the teachers look for a justification. The teachers always argue that they do not have an adequate time while the material is too many.

In a fact, the existence of PAI lesson is very important since it can internalize the spiritual value of the students (Yamani, 2016). Therefore, PAI lesson should have specific approach and method.

The appropriate method and approach is expected to increase the interest of the students toward PAI lesson. However, if the learning is not responded well, the PAI lesson will only be an accessory of religion without giving a positive contribution to improve the behavior and character of the nation. No wonder if the students get a perfect score in PAI lesson, it is not necessarily they will have a good behavior and character (Nasih, 2006).

PP. No. 19 year 2005 about the National Education Standard has mandated that the process of learning should be conducted inspirational, fun, challenging, and motivating the students to participate actively, creatively, and independently based on their talent, interest, physical and psychological development. This mandate will be hard to be achieved if there is no new breakthrough in learning method.

Based on the aforementioned explanation, PAI lesson needs to be conducted optimally to achieve the goal of PAI lesson. One of the ways is to use instructional media in accordance with the technological development and the students' condition.

Instructional media is a tool to deliver material to the students (Sadiman, 2008). Along with the technological development, the use of instructional media will attract the students' interest since the students have used to interact with gadgets and technology (Widiawati et.al 2014). Related to the urgency to the use of instructional media, so study related to this is very important to be conducted(Arifin, 2016). The study is beneficial as an evaluation for PAI lesson in elementary school and as a base to make policy. Based on the background of the study, this study aimed to analyze the use of instructional media in PAI lesson at elementary school in Malang. The purpose is to describe: (1) the method used in PAI lesson, (2) the use of instructional media in PAI lesson, (3) the availability of facilities in PAI lesson, and (4) the supporting and inhibiting factors in the use of media.

\section{METHOD}

The research method used in this study was quantitative approach by having a case study. This method can be used to develop a theory from a background of study (Bogdan \& Biklen, 1998). This method was expected to generate a theory by generalizing the implementation of method in improving the quality of PAI lesson.

The observation and multi-site used to collect the data. The researcher went to some schools in Malang and observed the learning of PAI lesson. This method used to examine the phenomenon in different schools. The data collection was conducted several times and the result was analyzed to generate a theory.

The population of this study was 5 elementary schools in Malang city, Malang district, and Batu city. The consideration in choosing the schools was the location and the quality of the schools. After long consideration, 5 schools were chosen; they are LB Elementary School, MR Elementary School, KL Dau Elementary School, ST Wagir Elementary School, and TSK Elementary School. The subject of this study was PAI teachers from those schools. The data sources were a document related to the availability and the quality of the facilities. In this study, the information in the form of words, setting situation, and other related documents were also collected. To collect the data, the researchers conducted observation about the schools and the learning of PAI lesson.

The technique used to collect data was interview, 
observation, and documentation. The data analyzed qualitatively through two steps: (1) during the process of data collection and after the process of data collection. The instruments were interview guideline, observation sheet, and checklist document. The data were analyzed qualitatively during and after the data collection.

Data analysis during site's data collection was conducted by following the process of Bogdan and Biklen (1998) during the process of data collection for three or four times. The process consisted of five steps analysis; they were (1) determining research focus, (2) organizing findings, (3) making a plan for data collection based on findings, (4) developing analytical questions for the next data collection, and (5) determining the target of the next data collection. In the analysis after the data collection, there were three steps conducted, they were: data reduction, data presentation, and findings.

\section{RESULTS AND DISCUSSIONS}

\section{Results}

This study revealed some findings about the learning method and the use of instructional media in PAI lesson at elementary schools in Malang.

\section{Learning Method in PAI lesson}

The learning activity is the most important part in the implementation of curriculum. The learning activities determine the efficiency and effectiveness of the learning process. Thus, the teachers should understand how to make an effective and efficient learning activity to meet the expected learning objective.

The main characteristic of the learning activities is an interaction, the interaction between students and learning environment, teacher, friends, tutor, instructional media, and other source of learning. Learning is also a system, which consists of learning components, such as the objective of learning, material, learning method, instructional media, evaluation, teachers and students (Sumiati \& Astra, 2009).

Method and technique of learning depend on the behavior in the objective of learning. Therefore, method and technique used for knowledge will be different with the method and technique used for skill and attitude.

The learning method used by the teachers in the teaching PAI lesson in elementary schools in Malang has been varied. This condition has happened in some of the elementary schools in Malang City, Batu City, and Malang district, in elementary schools with high to moderate quality.

The result of the interview and observation in LB Elementary Schools showed that PAI teacher has used varied method, such as: lecture, question and answer, experiment, demonstration, observation/ field study and assignment. The use of varied method gave a positive effect for the students, It made the students focus, active, and concern to the lesson. The use of the method was adjusted to the theme of the lesson. The lecture methods, the assignment, and the instructional media were used for the Akidah akhlak theme. The question and answer, the historic movie was used for historical theme. The demonstration of media, the question and answer were used for fiqih theme. The field study was used for Muamalah theme.

In SR Wagir Elementary School, PAI teacher used less methods, they were: lecture, practice, and role play. The teacher used fewer lectures and more practice. It was under the consideration that the headmaster wanted to habituate the students with the practice of the religion. Besides, the teacher assumed that the practice was the most effective way for the students in elementary school.

In KL Dau Elementary School, the method was more varied than SR Elementary School. In KL Dau Elementary School, the teachers used lecture, discussion, singing, role play, and games based on the standard competency. The teacher explained that varied method would eliminate the boredom and made the students more concentrate to the lesson. For the first and second grader, the students were taught to memorize the five pillars of Islam and the six pillars of Iman by singing.

The same condition happened to MR Elementary School. The method used by the teacher, including demonstration, storytelling, singing, lecture, game, question and answer, and depth interview. The teacher used variation method to eliminate the boredom. The use of method was also adjusted to the material and students' condition. Even if the students were happy with the method, the teacher stated that they were still unsatisfied and wanted to implement other methods.

The findings above showed that generally PAI the teachers have used varied method to eliminate students' boredom and make the students focus to the lesson (Darmadi, 2010). Besides, each student has unique tendency, intelligence, and different learning style, such as auditory, visual, and kinesthetic. 
The teachers need to aware that the students have different learning style. Thus, to accommodate all those learning styles, the teacher should use varied learning method (Silberman, 2004).

The selection of learning method should be adjusted with the education theory, they are the material, the objective of learning, and the students' condition. It is supported by Tafsir (2001) that the selection of effective learning method should consider the students' condition, the class, the objective of learning, the facilities, and the material. As a result, the suitable method will create an effective learning.

\section{The Instructional Media Variation in PAI Lesson}

The learning process is an educational interaction between students and teachers to achieve the objective of learning. This process is also an interaction among all of the components in the learning. One of the ways to achieve the objective of learning is to use the instructional media through an innovative learning.

Innovative learning is a student-centered learning. It means that the learning gives more opportunities to the students to self-directed and peer mediated instruction (Suardi, 2015). The independence of knowledge will be maximized if the teacher can maximize the existed instructional media.

In line with the varied method used in PAI lesson, the instructional media used has been varied since the instructional media variation depends on the method used. There was a variety of instructional media in PAI lesson, such as: poster, word-card, books, power point, and video.

In LB Elementary school, the teacher used visual media, audiovisual, and projected media (power point presentation). The use of media was depended on the theme. The teacher in LB Elementary School stated that visual media and picture were the most attractive media for the students. The word-card was also used in the learning, especially the material that needs dexterity and motoric development.

In SR Wagir Elementary School, the students tended to like audiovisual media. It was proven that during the video playback in Islam's holy day, the students' interest was increasing. In MR Elementary School, the media used was video, poster, juz'amma, internet, life model, and books. However, the educational video to raise the students' motivation was still become favorite media.

The variety of instructional media used by PAI teachers such as card, video, and power point facilitated the students to understand the lesson. According to PAI teacher in KL Elementary School, in the use of instructional media, the students liked two-way instructional media, which includes an interaction between communicator (teacher) and communican (students). The media should lead to the educational interaction.

The use of varied instructional media was an approriate method since the use of media attracted the students' interest and eased the students in understanding the lesson. According to Encyclopedia of Education Research that instructional media can increase the students' attention and ease the students' understanding (Hafid, 2015). It is supported by the findings, which stated that instructional media has a strategic role in motivating the students to learn (Fitriani, 2004). Conversely, the use of minimum instructional media makes the students bored and lazy to learn. As a result, the PAI lesson will not be effective.

\section{Discussion}

\section{The Supporting Facilities in PAI Lesson}

The facilities here mean the educational infrastructures utilize by the teachers and students to achieve the objective of learning. Based on the Sisdiknas regulation No 20 year 2003 article 45 paragraph 1 states that each of formal and non formal educational institution must provide infrastructures to fulfill the educational need which is appropriate with the physical development, intelligence, social, and emotional of the students". Therefore, the facilities are an absolute requirement to fulfill the need of learning process to develop the students' potency.

In relation to the learning process, the facilities have a function to determine the learning process and affect the students' achievement. The use of effective and efficient facilities will make the process of learning running well.

The supporting facilities in PAI lesson in elementary school were relatively diverse based on the geographical location of the school. The schools in urban area have adequate facilities such as mosque, hall, sound system, an equipped library, LCD and $\mathrm{CD} / \mathrm{VCD}$ projector, computer, supporting books, and others.

The facilities in LB Elementary School consisted of whiteboard and stationary, mosque, hall, conducive class, sound system, library, LCD projector, and computer. This school considered as a 
good school in providing facilities. MR Elementary School provided mosque, LCD, laptop, Al-qur'an, Islamic books, and Islamic History CD. The headmaster supported the availability of the facilities and make a learning video of the PAI lesson since the headmaster was Islamic teacher. The facilities in both schools were available, however the quality and the quantity needed to be enhanced.

KL Dau Elementary school provided mosque, library, and conducive class. There was no LCD projector in each class. The facilities needed to be enhanced. The teacher needed to find an adequate strategy to keep the concentration, thus the teacher tended to choose two-way learning method.

KL Wagir Elementary School was categorized as a school which provided less facilities. Basically, the school supported the provision of facilities, however the school was lack of resources. The facilities were lacking, the laptop was broken, there was no LCD and sound system. The lack of facilities affected the quality and performance of the teacher in the learning process.

From the above explanation, the availability of facilities in elementary school was generally adequate, except the TSK Elementary School, so the teachers could use the facilities according to the needs. This was a positive development since the facilities affect the achievement of the students (Dasam, 2010). Along with the development era, the students tend to use technology. Therefore the instructional media in learning should be improved.

Considering the urgency on the use of facilities in the learning process, the teachers should use the facilities optimally. The teachers can optimize the facilities for extracurricular activities, such as memorizing and writing Al-qur'an, calligraphy, the commemoration of the Islamic Holy day (PHBI), Islamic religious ritual, and Pesantren Ramadhan (Direktorat Jenderal Pendidikan Dasar Direktorat Pembinaan Sekolah Dasar, 2013). Based on Ahmad Tafsir, the Islamic activities are very important to foster the students to be a better Muslim (Tafsir, 2001).

\section{The supporting and Inhibiting Factors in The Use of Instructional Media}

From the study conducted in Malang, there were some supporting and inhibiting factors in the use of instructional media sourced from internal and external factors.

\section{Supporting Factors}

There are two aspects in supporting the use of instructional media in the PAI lesson, they are internal and external factors. There are two internal factors, they are (1) the capability of teacher in mastering IT and the appropriate method, and (2) the capability of teacher in making instructional media to develop their creativity.

The external factors are (1) the availability of facilities in PAI lesson and (2) the quality of the facilities in PAI lesson.

\section{Inhibiting Factors}

There are some internal factors that inhibit the use of instructional media in PAI lesson, they are (1) the limited time of the teachers to develop instructional media, since the teacher should teach in school and Islamic boarding school, (2) the limited number of teachers. It makes the innovation of instructional media in PAI lesson is limited, (3) the limited number of teachers to teach in class, thus the teachers are very busy, (4) the limited sources of facilities. The quality and quantity of facilities are very limited and need to be enhanced. It gets worse by the teachers' inability in operating technologies, such as LCD projector and computer.

The external factors are (1) the limited allocation time for PAI lesson, (2) the limited facilities, such as the broken facilities, and (3) the uncertainty of the curriculum. It makes the teacher confused to choose which method and media should be used.

\section{CONCLUSION}

The result of this study showed that the PAI teachers has used varied instructional media, such as visual and audio-visual media. The PAI teachers have also used varied method, such as demonstration, lecture, story telling, games, questions and answers, and role play. In choosing the method, the teacher always considers the students' condition. The use of varied method gives positive effects to the students, the students are more active and attracted to learn.

The supporting factor in the use of media is the ability of the teacher in utilizing and making instructional media. The availability of facilities also influences the use of media. However, there are some obstacle factors, such as the limited time of the teacher to develop media, the limited facilities in the schools, the limited time allocated for PAI lesson, and the uncertainty of the curriculum enacted.

\section{REFERENCES}

Arifin, M. Z. 2016. Membangun Paradigma Ilmiah pada 
Sistem Pendidikan Islam. Saintekbu, 4(1).

Bogdan, R. C. \& Biklen, S. K. 1998. Qualitative Research In Education: An Introduction to Theory and Methods. Boston: Allyn and Bacon.

Darmadi, H. 2010. Kemampuan Dasar Mengajar. Bandung, Alfabeta.

Dasam. 2010. Pengaruh Fasilitas Pembelajaran dan Kreativitas Guru terhadap Hasil Belajar Mata Pelajaran Akuntansi Pada Siswa Kelas XI SMK Negeri 9 Semarang Tahun Pelajaran 2009/2010. Skripsi, (online), (http://lib.unnes. ac.id/5192/1/6370A.pdf).

Direktorat Jenderal Pendidikan Dasar Direktorat Pembinaan Sekolah Dasar. 2013. Panduan Pembinaan Kegiatan Ekstrakurikuler Keagamaan Sekolah Dasar dan Madrasah Ibtidaiyah. Jakarta: Kementerian Pendidikan dan Kebudayaan RI.

Fitriani, P. N. 2004. Penggunaan Media Pembelajaran Pendidikan Agama Islam Dalam Meningkatkan Motivasi Belajar Siswa Kelas VII SMP Birrul Walidain Sragen Tahun Ajaran 2013/2014. Skripsi, (online), (http://eprints.ums.ac.id/30834/13/02. NASKAH_PUBLIKASI.pdf).

Hafid,N.A.InovasiMediaPembelajaran.(Online),(http:// www.lpmpsulsel.net/ v2/index.php?option= com_content\&view $=$ article $\&$ id=348:inovasipembelajaran \&catid $=42$ : ebuletin\&Itemid=215).

Himam, F. 2016. Situated Learning dan Strategi Transfer Kepemimpinan. Buletin Psikologi, 13(1): 45-54.

Nasih, A. M. 2006. Pembelajaran Akhlaq pada Siswa
Sekolah Dasar melalui Pemanfaatan Beritaberita Media Masa. Jurnal Sekolah Dasar. Kajian Teori dan Praktik Pendidikan, 15(2).

Nurhadi, dkk. 2004. Pembelajaran Konstektual dan Penerapannya dalam KBK. Malang: UM Press.

Peraturan Pemerintah Republik Indonesia Nomor 19 Tahun 2005 Tentang Standar Nasional Pendidikan.

Pusat Kurikulum Depdiknas. 2004. Standar Kompentensi Mata Pelajaran Agama Islam Sekolah Dasar dan Madrasah Ibtidaiyyah. Jakarta: Depdiknas.

Sadiman, A. S. 2008. Media Pendidikan. Jakarta: Raja Grafindo Persada.

Silberman, M. R. 2004. Active Learning: 101 Cara Belajar Siswa Aktif. Terjemahan Raisul Muttaqien. Bandung: Nusamedia dan Nuansa.

Suardi, M. 2015. Belajar dan Pembelajaran. Yogyakarta: Deepublish.

Sumiati \& Asra. 2009. Metode Pembelajaran. Bandung: CV. Wacana Prima.

Tafsir, A. 2001. Metodologi Pengajaran Agama Islam. Bandung: Remaja Rosdakarya.

Undang-Undang Republik Indonesia Nomor 20 Tahun 2003 Tentang Sistem Pendidikan Nasional.

Widiawati, I., Sugiman, H., \& Edy. Pengaruh Penggunaan Gadget terhadap Daya Kembang Anak, Prosiding Seminar Nasional Multidisiplin Ilmu. Jakarta: Universitas Budi Luhur, 10 Mei 2014. ISSN : 2087 - 0930.

Yamani, M.T. 2016. Urgensi dan Signifikansi Pendidikan Islam Berwawasan Multikultural. J-PAI, 1(1). 